\title{
Treatment of a tooth with furcation involvement and extensive alveolar bone resorption due to endodontic-periodontal combined lesion using root resection: a case report
}

\author{
Youn-Kyung Choi ${ }^{1}$, So-Yeun Kim¹, Hye-Mi Jeon ${ }^{1}$, Kyoung-Hwa Jung ${ }^{1}$, Na-Rae Choi ${ }^{2}$, Ji-Young Joo ${ }^{3}$, Hyun-Joo Kim ${ }^{4}$, and \\ Eun-Young Kwon *
}

${ }^{1}$ Clinical Associate Professor, Dental Clinic Center, Pusan National University Hospital, Busan, Republic of Korea

${ }^{2}$ Clinical Assistant Professor, Dental Clinic Center, Pusan National University Hospital, Busan, Republic of Korea

${ }^{3}$ Associate Professor, Department of Periodontology, Dental and Life Science Institute, School of Dentistry, Pusan National University, Yangsan, Republic of Korea

${ }^{4}$ Assistant Professor, Department of Periodontology, Dental and Life Science Institute, School of Dentistry, Pusan National University, Yangsan, Republic of Korea

Due to the complex anatomical structure of the molar, endodontic-periodontal combined lesions often occur, resulting in furcation involvement and extensive alveolar bone resorption. When endodontic-periodontal combined lesions occur through the apical foramen and the periodontal tissue is destroyed up to the furcation, root canal therapy after a surgical periodontal treatment is performed if necessary. However, if a normal healing process does not occur after conventional treatment, root resection, which removes only the affected root that is the source of infection, may be a good alternative. The purpose of this study is to report a case of the maxillary molar with furcation involvement and extensive alveolar bone resorption due to an endodontic-periodontal combined lesion that had been preserved by root resection.

Key Words: Alveolar bone loss; Periodontal attachment loss; Periodontal diseases; Root canal therapy

(c) This is an open-access article distributed under the terms of the Creative Commons Attribution Non-Commercial License (http://creativecommons.org/licenses/by-nc/4.0) which permits unrestricted noncommercial use, distribution, and reproduction in any medium, provided the original work is properly cited.

\section{Introduction}

대구치의 복잡한 해부학적 형태는 치수 감염이 발생 시 근관 치료를 통한 근관 내 염증 물질의 완전한 제거를 어렵게 만든다 [1]. 상악 대구치의 경우 근심협측 부근관이 종종 존재하기도 하 며, 대구치 이개부 부위의 $76 \%$ 에서 부근관이 존재한다고 보고 된 바가 있다[2,3]. 대구치의 특수한 구조로 인해 종종 염증 부 산물이 치근단공을 지나서 치주조직까지 확산되어 치수-치주조 직의 개통이 일어나면서 치주-근관 복합병소가 발생하기도 하
며, 치근이개부 치주조직의 파괴를 동반하기도 한다[2]. 진행된 치근이개부 병변을 가지고 있는 대구치는 단근치나 치근이개부 병변을 가지고 있지 않은 대구치에 비해 치주치료에 대한 반응 이 덜 호의적이며, 치주 부착 소실 및 발치의 가능성이 더욱 높 다고 보고되어 왔다[4,5].

치근이개부 병변을 가지고 있는 대구치의 치료는 치주치료 영역에서 큰 임상적 도전으로 이개부 병변의 깊이 정도에 따라 치료방법이 결정된다[6]. 1도 정도의 초기 치근이개부 병변에는 비외과적 처치 즉, 치석제거술 및 치근활택술 만으로도 치료할

Received February 18, 2021; Revised [1] February 25, 2021; [2] March 4, 2021; [3] March 4, 2021; Accepted March 4, 2021

${ }^{*}$ Corresponding author: Eun-Young Kwon, Dental Clinic Center, Pusan National University Hospital, 179 Gudeok-ro, Seo-gu, Busan 49241, Republic of Korea.

Tel: +82-51-240-7429, Fax: +82-51-240-7706, E-mail: betteryoung@hanmail.net 
수 있으나, 2도 및 3도의 진행된 치근이개부 병변이 존재 시 비 외과적 처치에 대한 반응이 덜 호의적이다[7]. 따라서 진행된 치 근이개부 병변이 존재시 외과적 처치인 치근이개부 성형(furcation plasty), 터널화(tunnel preparation), 삭제형 술식, 재생 술 식 또는 발치 등을 고려해야만 한다[6]. 그 중에서도 삭제형 술 식이 흔히 사용되는데, 여기에는 치근 절제술(root resection)과 편측절단술(hemisection)이 있다[8]. 편측절단술은 치근이개부 병변이 존재하는 대구치를 2개의 단근치로 분리시키는 반면, 치 근 절제술은 이환된 치근만을 제거하고 치관과 나머지 치근은 기능을 유지하도록 남겨두는 술식이다[2,7]. 치근 절제술을 통 해 구강위생을 용이하게 하는 환경을 만들 수 있고, 임플란트 식 립을 어렵게 만드는 해부학적 구조물이 존재 시에도 발치 및 임 플란트를 하지 않고 자연치를 유지할 수 있다[5,9].

치주-근관 복합병소가 발생하여 치수-치주조직의 개통이 일 어나고, 대구치의 치근이개부까지 치주조직이 파괴된 경우 일 반적으로 근관치료를 시행 후 필요 시 재생형 골수술 등의 외과
적 치주처치를 시행한다. 그러나 치주-근관 복합병소로 인해 치 근이개부에 이르는 광범위한 골흡수가 일어났거나, 통상적 치 료 이후에도 감염원이 잔존하여 정상적인 치유 과정이 일어나 지 못한다면, 발치를 고려할 수도 있다. 그러한 경우 이환된 치 근만을 절제하여 감염원을 원천적으로 제거하는 치근 절제술이 좋은 대안이 될 수 있다. 본 연구에서는 치주-근관 복합병소로 인해 치근이개부 병변 및 광범위한 골소실을 나타내는 상악 대 구치에서 치근 절제술을 이용하여 성공적으로 보존하여 사용하 고 있는 증례를 보고하고자 한다.

\section{Case}

56세의 여자 환자가 상악 우측 제1대구치(\#16) 부위가 자주 붓고 저작 시 통증 등의 불편감이 느껴진다는 주소로 치주과에 내원하였다. 임상 검사 결과 \#16 부위의 원심 협측 치근 주위에 서 치은 부종, 탐침시 출혈 및 $9 \mathrm{~mm}$ 이상의 깊은 치주낭 깊이

Table 1. Changes in clinical parameters on the distobuccal area of the maxillary right 1st molar

\begin{tabular}{lccccc}
\hline Parameters & 1st visit & $\begin{array}{c}\text { 3-month follow-up } \\
\text { after OFD }\end{array}$ & $\begin{array}{c}\text { 1-year follow-up } \\
\text { after RCT }\end{array}$ & $\begin{array}{c}\text { 1-year follow-up } \\
\text { after root resection }\end{array}$ & $\begin{array}{c}\text { 5-year follow-up } \\
\text { after root resection }\end{array}$ \\
\hline PD & $9 \mathrm{~mm}$ & $9 \mathrm{~mm}$ & $8 \mathrm{~mm}$ & $2 \mathrm{~mm}$ & $2 \mathrm{~mm}$ \\
$\mathrm{CAL}$ & $9 \mathrm{~mm}$ & $11 \mathrm{~mm}$ & $10 \mathrm{~mm}$ & $4 \mathrm{~mm}$ & $4 \mathrm{~mm}$ \\
BOP & + & + & + & - & - \\
Mobility & - & - & - & - & - \\
\hline
\end{tabular}

OFD, open flap debridement; RCT, root canal therapy; PD, probing depth; CAL, clinical attachment level; BOP, bleeding on probing.
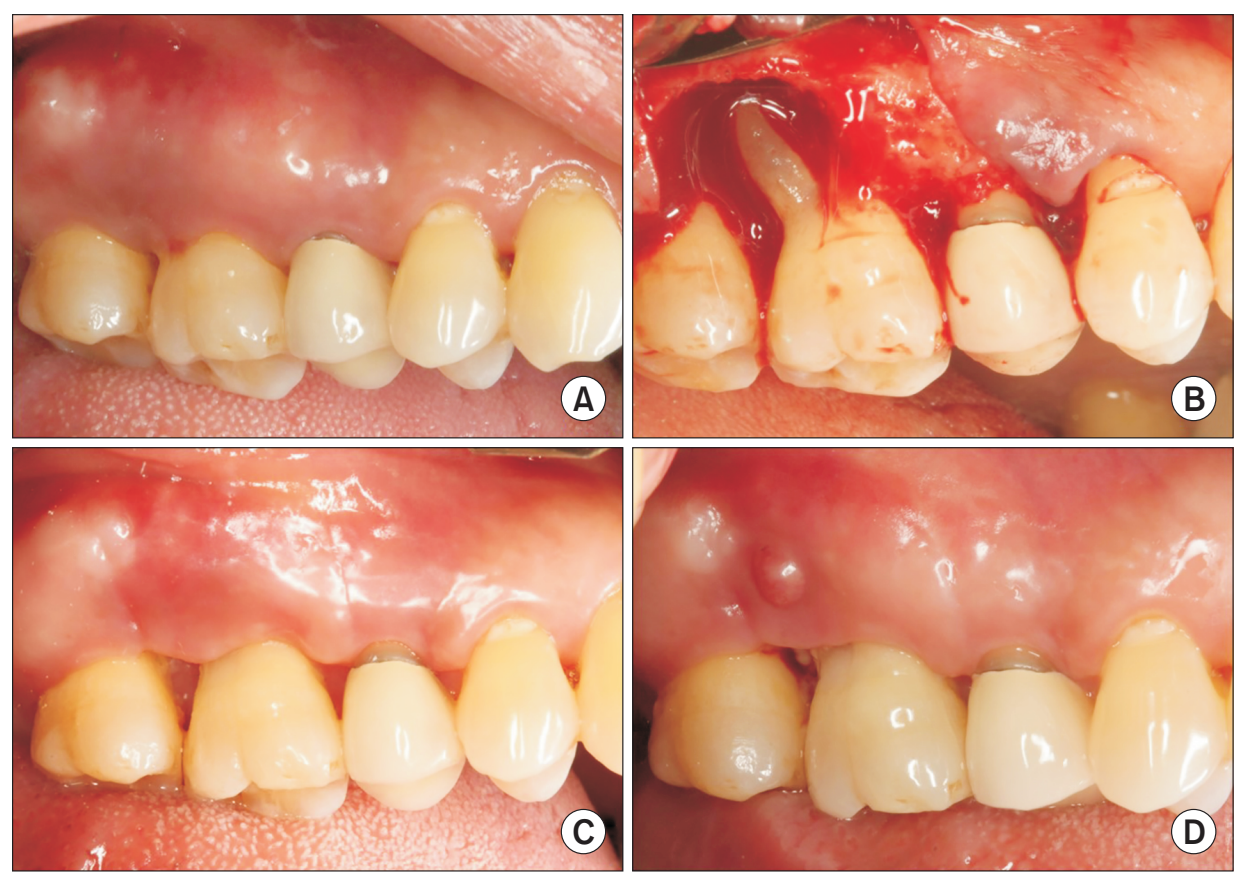

Fig. 1. Clinical photograph. (A) Initial photograph, (B) after removal of granulation tissue after flap reflection, (C) follow-up after 1 month, (D) follow-up after 3 month (just before the start of root canal therapy). 
및 임상적 부착 수준이 관찰되었다(Table 1, Fig. 1A). 동요도는 관찰되지 않았으며, 전기 치수 검사상 양성 반응을 보였다. 치근 단 방사선 사진에서도 \#16 부위의 원심 협측 치근에서 치근단 부위까지 방사선 투과상 병소가 관찰되었다(Fig. 2A). 해당 치 아에서 일차적으로 발치를 고려할 수도 있으나, 동요도가 없고,
원심 협측 치근을 제외한 나머지 치근 주위에서는 비교적 건전 한 잔존골이 관찰되어 비외과적 치주치료를 먼저 시행하고, 이 후 외과적 치주치료를 통해 치아를 보존하고자 계획하였다. 본 증례에서 해당 치아는 원심협측 치근 주위에서 치근단에 이르 는 골흡수를 보였으나 전기 치수 검사에서 양성 반응을 보였고,
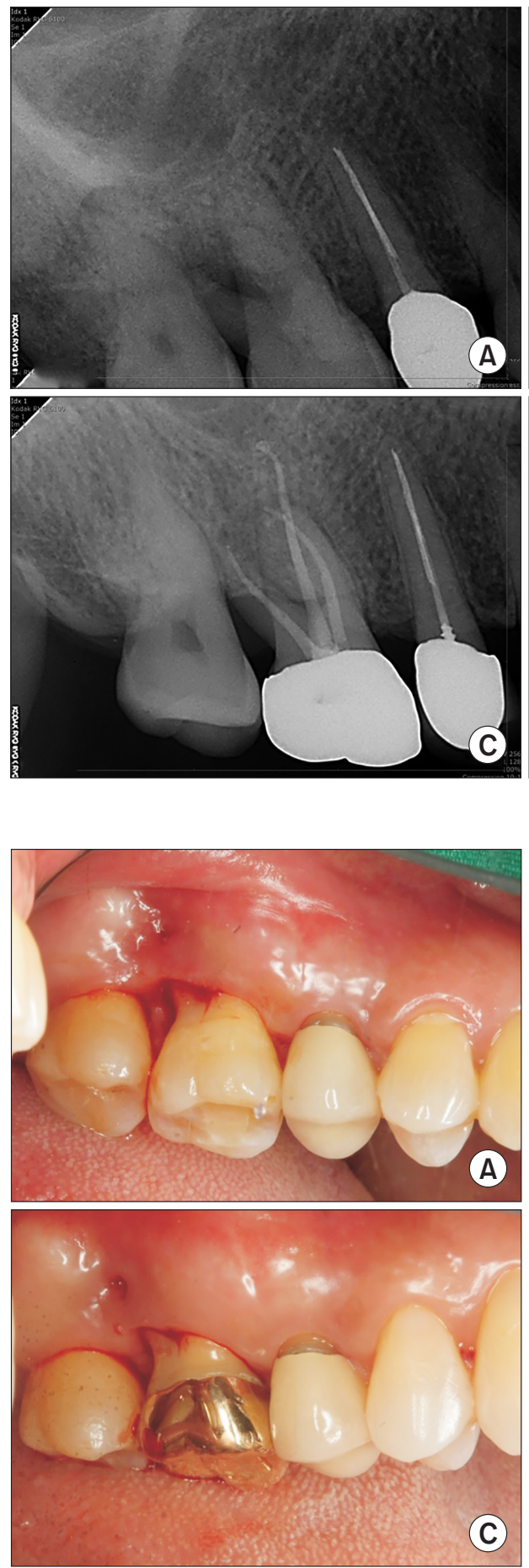
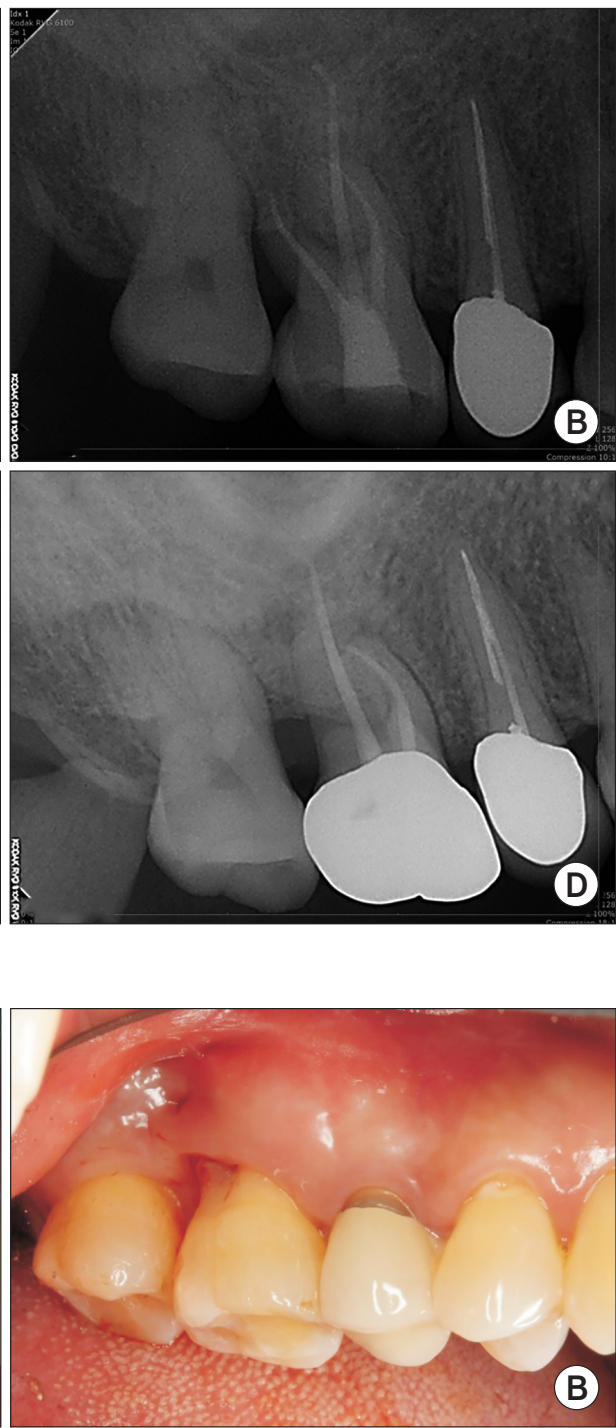

Fig. 2. Periapical radiography. (A) Initial radiography, (B) three months after root canal therapy, (C) nine months after root canal therapy, (D) three months after root resection.

Fig. 3. Clinical photograph. (A) Immediately after root canal therapy, (B) three months after root canal therapy, (C) nine months after root canal therapy, (D) ten months after root canal therapy. 
깊은 치주낭과 치은 부종 등의 만성 치주염 징후를 보였기에 치 주질환에 의한 골흡수라 판단하고 근관치료는 처음부터 시행 하지는 않았다. 치태조절 교육, 치석제거술 및 치근활택술 등의 비외과적 치주치료 이후 잔존한 광범위한 골흡수 부위를 처치 3 기 위하여 외과적 치주치료를 시행하였다. 상악 우측 구치부에 1:100,000 에피네프린이 포함된 2\% 리도카인(Lidocaine; Huons, Seongnam, Korea)을 이용하여 침윤 마취를 시행하고 15 번 외과용 수술도로 열구 내 절개 후 판막을 거상하였다. \#16의 협측에서 원심에 이르는 3도의 치근이개부 병변 뿐만 아니라 원 심협측 부위에서 치근단 하방까지 진행되어 있는 광범위한 골 흡수 부위가 관찰되었다(Fig. 1B). 골내 결손부에 잔존하는 육아 조직을 먼저 소파하고 치근면에 부착되어 있던 치석을 제거하 였다. 이후 골이식술이나 조직유도 재생술과 같은 재생형 골수 술을 고려할 수 있으나 복잡한 치근 내부까지 완전히 debridement를 하기에 어려움이 있었고 국소 인자가 모두 제거되지 못 한 채로 재생형 골수술을 시행하는 것은 바람직하지 않다고 판 단하여 debridement만 시행하고 봉합하였다. 술 후 1 개월 경 과 시 특이사항 없었으나(Fig. 1C), 술 후 3개월째 원심 협측 치 근 주위로 누공이 관찰되었다(Fig. 1D). Gutta-percha tracing 으로 원심 협측 치근단 부위에 문제가 있음을 확인 후 치주-근 관 복합병소라 판단하고 근관치료를 진행하였다. 근관치료 완 료 후 3개월까지 경과 관찰 시 환자의 불편감은 사라졌고 누공 의 크기가 줄어드는 것을 확인하였다(Fig. $3 \mathrm{~A}, \mathrm{~B}$ ). 근관치료 6개 월째 금관 수복을 시행하였으나 이후 경과 관찰 시 치은 천공이 발견되었다. 또한 시간이 경과할수록 치은 천공의 크기가 커지
는 것이 관찰되었다(Fig. 3C, D). 치주낭 측정 시 원심 협측 치 근 주위로 $8 \mathrm{~mm}$ 이상의 치주낭 깊이를 확인하였으며 원심 협 측 치근 주위로 광범위한 골소실이 잔존해 있음을 예상하였다. 이러한 경우 발치를 고려할 수도 있었으나 최대한 자연치를 보 존하기 위하여 근관치료 완료 1년째 원심 협측만 제거하는 치 근 절제술을 시행하기로 결정하였다(Fig. 4A).\#16 협측 부위에 침윤 마취를 시행 후 판막을 거상하였고, 원심 협측 치근 주변으 로 깊고 넓은 골 결손부가 잔존함을 확인하고 치근 절제술을 시 행하였다(Fig. $4 \mathrm{~B}, \mathrm{C}$ ). 이 때 절제한 치근 내면에는 이전의 외과 적 치주처치 시 제거되지 못한 치석이 관찰되었다(Fig. 4D). 원 심 협측 치근을 절제 후 ledge가 생기지 않도록 다듬어주고, 치 근이 절제된 공간과 인접 치근 표면에서 debridement를 시행 하고 봉합하였다(Fig. $5 \mathrm{~A}$ ). 술 전에는 동요도가 관찰되지 않았으 나 치근 절제술 2 주 후 봉합사 제거 시 1 도의 동요도가 관찰되 었다. 이후 3 개월 지난 시점에서 경과 관찰 시 해당 치아에서 동 요도가 없음을 확인하였다(Fig. $5 \mathrm{~B}$ ). 1 년의 경과 관찰 기간 동안 \#16 원심 협측 치주낭 깊이는 $3 \mathrm{~mm}$, 임상적 부착 수준은 $4 \mathrm{~mm}$ 로 유지되었고 동요도나 탐침 시 출혈, 부종은 관찰되지 않았다 (Table 1, Fig. 5C). 치근단 방사선 사진에서 근관치료 후 치근 절제술 시행 이후 5 년의 경과 관찰 기간 동안 원심 협측 치근 주 위로 추가적인 골소실 없이 치조골 수준이 잘 유지되고 있음이 관찰되었다(Fig. 2B-D, 6). 치근 절제술 이후 정기 점검 시 환자 의 치태 조절능력을 지속적으로 평가하였으며, 교합 간섭이 발 생하지 않도록 필요 시 교합조정을 시행하였다.
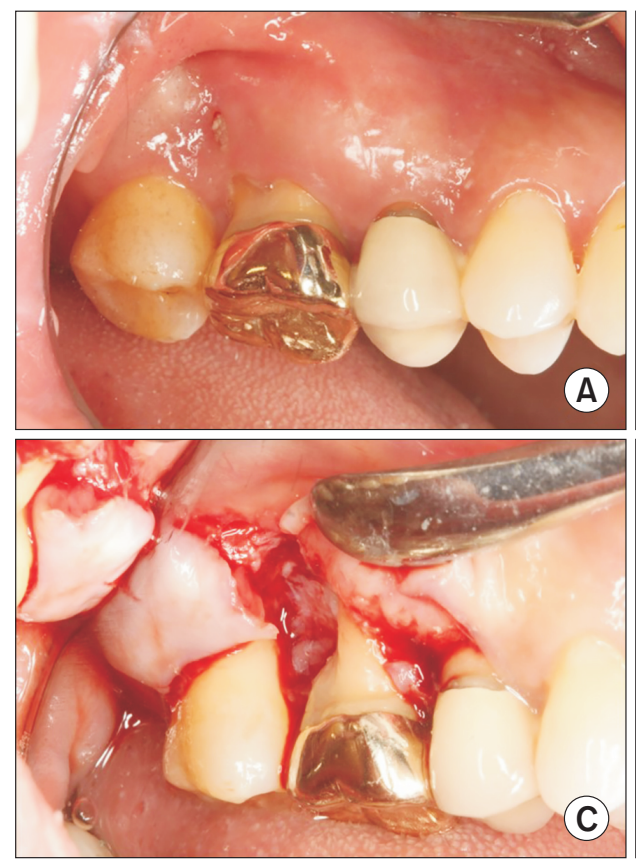
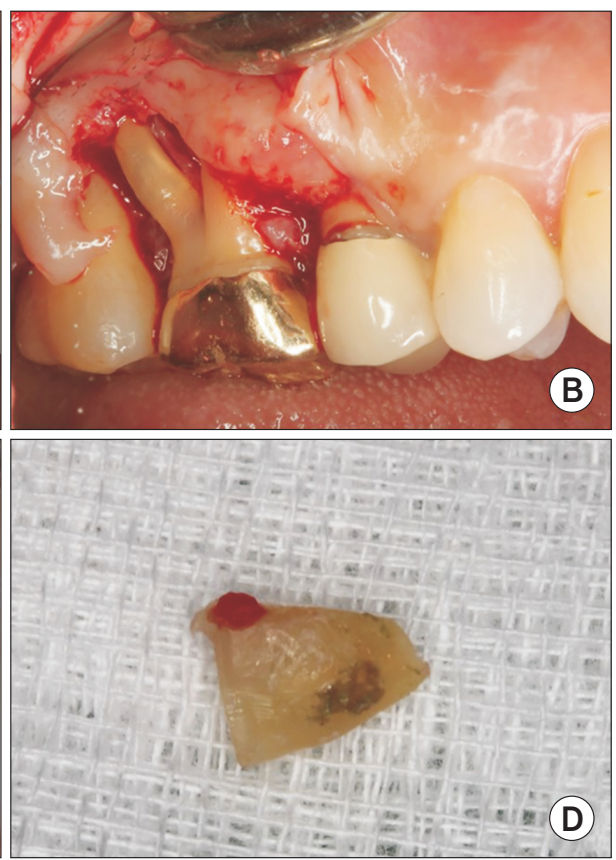

Fig. 4. Clinical photograph. (A) One year after root canal therapy (just before flap elevation), (B) after flap elevation, (C) after root resection of distobuccal root, (D) remained calculus at the resected root inner surface.

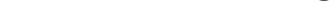



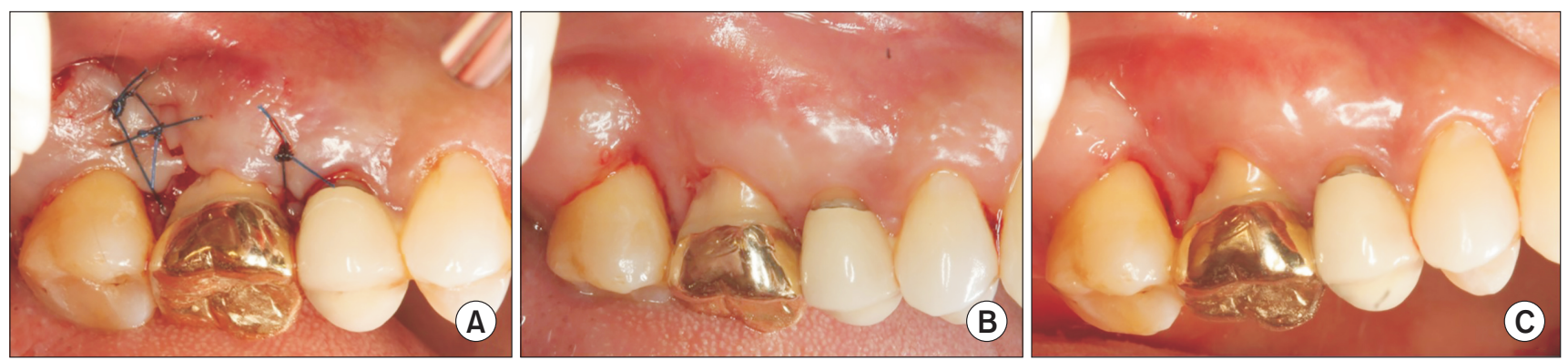

Fig. 5. Clinical photograph. (A) After debridement and suture, (B) three months after root resection, (C) one year after root resection.

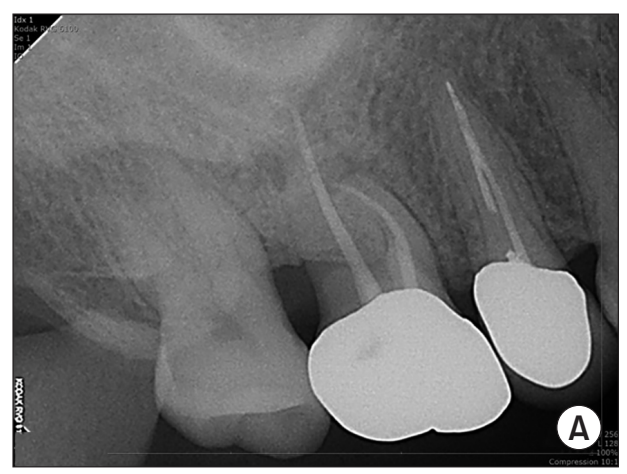

\section{Discussion}

치주질환에 이환된 상악 대구치의 치료는 특별한 도전을 부여하는데, 이는 이개부의 존재뿐만 아니라 치근 근접(root proximity) 및 상악동의 존재 등으로 인함이다. 이전의 연구에 따르면, 상악 대구치는 하악 대구치보다 치근이개부 병변 진단 을 더 흔히 받는 것으로 알려져 있고, 그 중에서도 상악 제2대구 치에 비해 제 1 대구치가 치근 절제술을 받는 빈도가 훨씬 높았다 [5,10]. 또한 그 중에서도 근심 치근보다 원심 협측 치근이 절제 되는 경우가 가장 많다고 알려져 있다[8,11]. 이것은 상악 제 1 대 구치의 원심 협측 치근 주위로 치태 조절 시 제한된 접근성과 상 악 제 2 대구치의 근심 협측 치근과의 근접성으로 인해 얇은 치간 부 골 중격(bony septum)이 존재하게 되고, 이로 인해 제1대구 치의 원심 협측 치근 주위 치주 상태가 악화되는 것과 연관되어 있다[8].

또한 상악 대구치는 하악 대구치에 비해 자가 및 전문가 치태 조절 시 이개부 입구로의 접근성이 떨어지고, 이개부 입구의 개 수도 많으므로 이개부 병변에 이환될 확률이 높다[5]. 본 증례에 서 상악 제 1 대구치인 해당 치아 병변의 원인은 수술 당시의 모 습으로 추정해 보았을 때, 원심 협측 치근 주위에서 치조정에서 부터 치근 이개부까지 광범위한 골소실을 유발시킨 치주-근관 복합 병소로 생각되었다. 이러한 경우 1차적인 치수질환에 의한
복합 병소인지 1차적인 치주질환에 의한 복합 병소인지 근본적 인 원인을 찾기는 어려우나, 본 증례에서는 절제한 치근 내면에 서 이전의 외과적 치주처치 시 제거되지 못한 치석이 관찰된 것 으로 보아 1차적인 치주질환이 분명히 존재하였음은 추정할 수 있었다.

일부 연구에서는 치근단 병소나 광범위한 치조골 소실이 존 재 시 조직유도재생술과 같은 재생형 술식이 좋은 치료 결과를 유도한다고 발표하였다[12]. 그러나 상악 대구치에서 치근이개 부 병변 및 광범위한 골소실이 존재하여 외과적 치주치료가 필 요할 때 기구 접근의 어려움 때문에 골이식술 및 조직유도재생 술과 같은 재생형 골수술의 적용은 제한적일 수밖에 없으며, 이 런 경우 치근 절제술을 고려해볼 수 있다[2,9]. 치근 절제술은 치 주질환에 이환된 대구치에서 박테리아 저장소로 기능할 수 있 는 불리한 해부학적 구조물들 뿐만 아니라 침착된 박테리아와 치석을 근본적으로 제거할 수 있게 해 준다[13]. 특히 의문이 되 는 치아가 구강 내에서 매우 높은 전략적 가치를 지니고 있거 나 다른 치료법으로는 해결될 수 없는 경우에 치근 절제술은 유 용한 술식이 될 수 있다[14]. 본 증례에서도 외과적 치주처치를 위해 첫 번째로 판막을 거상했을 때 일차적으로 골이식술 및 조 직유도재생술과 같은 재생형 골수술을 고려해 볼 수도 있었으 나, 복잡한 이개부 내면까지 기구 접근이 어려웠다. 이에 완벽 한 debridement가 불가능하다고 판단하여 재생형 골수술을 하 
기에 부적합하다고 생각하였으므로 이식재를 사용하지 않았다. 근관치료 1년 경과 후 두 번째로 외과적 처치를 위해 판막을 거 상하였을 때도 이개부 병소 내면까지 기구 접근이 어려워 재생 형 골수술은 고려하지 않고 이환된 원심 협측 치근만을 절제하 였으며 치료 후 5년째까지 구강 내에서 유지되고 있었다.

자연치를 보존하기 위한 치근 절제술을 위해서는 복잡한 과 정들이 요구되고, 치주치료, 근관치료 뿐만 아니라 필요 시 수 복 치료까지 동반되어야 한다[2]. 이전에는 치근 절제술로 치료 되었을 치아들이 최근에는 발치되고 임플란트로 대체되는 경우 가 많아졌는데, 이것은 임상가들에게 치근 절제술이 임플란트 보다 더 도전적인 술식으로 여겨지는 것과 관련이 있을 것이다 [7]. 여러 연구들에서 치근 절제술과 임플란트 술식의 예후를 비 교하였으며, 일부 학자들은 단일 임플란트 에 비해 치근 절제술 에서 실패율이 더 높으며, 치근 절제술은 고도로 높은 수준의 치 료가 뒷받침되지 않으면 나쁜 장기간의 결과를 야기한다고 하 였다[12,15]. 반면, 일부 학자는 치근 절제술과 임플란트 술식은 둘 다 높은 정도의 성공률을 보인다고 보고하였다[12,16]. 비록 임플란트는 여전히 인기 있는 치료 방법이나, 침습적 술식이며, 임플란트 주위염과 같은 다양한 합병증을 동반할 수 있다. 특히 상악 구치부에서 해면골질(spongiosa bone quality), 수직적 치 조골 흡수, 상악동의 존재 등으로 인하여 상대적으로 높은 임플 란트 실패율을 관찰할 수 있다[2]. 또한 치주질환이나 근관 내 문제를 가지고 있는 자연치가 오히려 임플란트의 평균 수명을 능가한다는 보고도 존재한다[7,17]. 상악 대구치의 치근 하나를 절제한다고 해서 정상 저작 기능 시 해당 치아의 동요도가 증가 하지 않으며 구강 내에서 교합력을 감당할 수 있는 것으로 알려 져 있다[2]. 본 증례에서도 치주-근관 복합 병소로 인해 광범위 한 골소실 및 치근 이개부 병변을 보였던 상악 대구치에서 치근 절제술을 통하여 발치하지 않고 5년 이상 보존하여 동요도 없이 환자가 사용할 수 있었다. 만일 본 증례에서 발치 후 임플란트를 식립하려고 했다면, 발치 전 존재했던 치근이개부 병변 부위에 서 심한 골흡수로 임플란트 식립 시 광범위한 치조골 결손부 골 이식술을 필요로 할 것이며, 보철물 장착 이후에도 식편 압입 등 으로 인한 임플란트 주위염과 같은 합병증이 발생할 수도 있었 을 것이다.

치근 절제술 시 다양한 사항들을 고려해야 하는데, 먼저 환자 의 나이 및 전신 건강 상태, 치태 조절 능력, 우식 이환율(individual caries rate) 그리고 복잡한 치료를 견딜 수 있는 심리적, 재정적 상태 등을 고려해야 한다. 또한 해당 치아의 전략적 가 치, 치주 파괴의 정도와 이개부 병변의 정도, 치근 절제술 이후 의 잔존 치근의 형태 및 동요도, 근관치료를 받고 수복할 수 있 는지 여부, 상악동저 또는 하치조 신경 위치, 잔존 치조골의 양 과 질 등을 술 전에 미리 평가해 보아야 한다[5,15]. 치근 절제술
이후의 생존율, 성공률에 대해서는 문헌마다 다르게 보고하고 있으며, 특히 치근 절제술 시 잔존 치근의 골 지지가 치주질환 을 가진 대구치의 생존율에 매우 큰 영향을 미친다고 보고되었 다. 특히 치주질환에 이환된 대구치에서 좋은 결과를 얻기 위해 서는 치근 절제술 시 잔존 치근의 $50 \%$ 이상의 골 지지가 중요한 요소라고 알려져 있다[2,13]. 본 증례에서 환자는 복잡한 치료를 받을 수 있는 전신적으로 건강한 상태였으며, 구강 위생 관리 능 력이 높았으며, 원심 협측 치근 이외의 치근 주위에서 충분한 잔 존 치조골이 존재하였고, 근관치료 및 수복에 어려움이 없는 상 태였다. 이에 치주 판막술 및 근관치료 이후에도 원심 협측 치근 주위로 잔존한 광범위한 치조골 소실과 이에 따른 치은 천공을 해결하기 위해 치근 절제술을 시행하였다.

치근 절제술은 다양한 합병증들과 연관되어 있는데, 여기에 는 치태 조절의 어려움, 치근 절제한 대구치의 수복 문제, 치근 우식 등이 포함된다[4]. 상악에서 하악 대구치보다 치근 절제술 이 실패가 많다고 알려져 있는데, 이것은 방사선 사진에서 보이 지 않는 치근 절제술 후 치근 표면에 남은 lips와 ledges 때문이 다[12,18]. 따라서 상악 대구치의 치근 절제술 시행 시 이개부 함요부(furcal concavities)를 간과해서는 안 되며 치근 절제술 이후 구강 위생이 원활히 이루어질 수 있는 환경을 만들어 주도 록 주의해야 한다. 만일 치근 절제술을 하기로 결정했다면, 치근 절제술 후 이러한 합병증들이 발생하지 않도록 철저한 보조적 치주 치료를 통해 유지 관리되어야 하며 환자는 철저한 구강 위 생 관리를 집에서 해야만 한다. 또한 술자는 매우 정확하나 보존 적인 근관치료를 시행하고 및 환자가 치태 조절을 하기에 용이 한 형태의 보철물 제작을 하도록 계획해야 한다[7]. 보철물의 생 존을 위해 교합력은 중요하게 고려해야 하며, 치근 절제술을 받 은 대구치의 수복 시 교합력이 분산 되도록 보철물 제작을 해야 하며, 잔존 치근에는 가장 약한 load만이 가해질 수 있도록 주 의해야 한다[13]. 본 증례에서도 상악 대구치의 치근 절제술 시 ledge가 발생하지 않도록 주의하였으며, 치근 절제술 이후 치관 수복물 주위로 구강 위생 관리가 원활히 이루어지는지 정기점 검을 통해 확인하였다. 또한 이 때 부적절한 교합 간섭이 발생하 지 않는지 관찰하였으며 필요 시 교합조정을 시행하였다.

일부 연구에서는 치주 조직의 재생을 촉진하기 위해 치근 절 제술 시행 시 치근을 제거한 후 골 이식술 및 조직유도재생술과 같은 재생형 치주수술을 동시에 시행하기도 하였다[2]. 그러나 본 증례에서는 치근 절제술 직후 상악 대구치 치근의 복잡한 해 부학적 형태 때문에 잔존 치근 주위에서 완전한 debridement 자체가 매우 어려웠고, 치근을 제거하고 후 판막의 일차 봉합 (primary closure)을 얻는 것이 불가능하다고 판단하여 재생형 치주수술은 시행하지 않고 오직 치근 절제술만 시행하였다. 이 후 추적 관찰 기간 동안 치근이 절제된 빈 공간에서 더 이상의 
치조골 소실은 발생하지 않음을 확인할 수 있었다.

종합해보면, 치주-근관 복합병소로 인해 치근 이개부 병소 및 치근 주위로 광범위한 골흡수가 발견될 때 대구치 치근의 복잡 한 해부학적 구조물 때문에 기존의 비외과적 또는 외과적 치주 치료, 근관치료로 해결되지 못하고 발치로 연결되는 경우가 많 다. 이러한 경우 치근 절제술을 통해 경우에 따라 치아를 보존할 수 있으므로 발치 및 임플란트 치료를 계획하기 전 최후의 수단 으로 고려해 볼 수 있을 것이다.

\section{Acknowledgements}

This work was supported by clinical research grant from Pusan National University Hospital in 2021.

\section{Conflicts of Interest}

The authors declare that they have no competing interests.

\section{ORCID}

\author{
Youn-Kyung Choi \\ https://orcid.org/0000-0003-1491-2986 \\ So-Yeun Kim \\ https://orcid.org/0000-0001-6714-8315 \\ Hye-Mi Jeon \\ https://orcid.org/0000-0003-0007-5662 \\ Kyoung-Hwa Jung \\ https://orcid.org/0000-0002-8305-0016 \\ Na-Rae Choi \\ http://orcid.org/0000-0002-5251-0825 \\ Ji-Young Joo \\ https://orcid.org/0000-0002-4050-5797 \\ Hyun-Joo Kim \\ https://orcid.org/0000-0001-7553-6289 \\ Eun-Young Kwon \\ https://orcid.org/0000-0001-9555-0360
}

\section{References}

1. Singh P. Endo-perio dilemma: a brief review. Dent Res J (Isfahan) 2011;8:39-47.

2. Oh SL. Mesiobuccal root resection in endodontic-periodontal combined lesions. Int Endod J 2012;45:660-669. doi: 10.1111/j.1365-2591.2012.02020.x.

3. Pattanshetti N, Gaidhane M, Al Kandari AM. Root and canal morphology of the mesiobuccal and distal roots of permanent first molars in a Kuwait population--a clinical study. Int Endod J 2008;41:755-762. doi: 10.1111/j.13652591.2008.01427.x.

4. Hou GL, Tsai CC, Weisgold AS. Treatment of molar furcation involvement using root separation and a crown and sleeve-coping telescopic denture. A longitudinal study. J Periodontol 1999;70:1098-1109. doi: 10.1902/ jop.1999.70.9.1098.

5. Lee KL, Corbet EF, Leung WK. Survival of molar teeth after resective periodontal therapy--a retrospective study. J Clin Periodontol 2012;39:850-860. doi: 10.1111/j.1600051X.2012.01918.x.

6. Svärdström G, Wennström JL. Periodontal treatment decisions for molars: an analysis of influencing factors and long-term outcome. J Periodontol 2000;71:579-585. doi: 10.1902/jop.2000.71.4.579.

7. Mokbel N, Kassir AR, Naaman N, Megarbane JM. Root resection and hemisection revisited. Part I: a systematic review. Int J Periodontics Restorative Dent 2019;39:e11-e31. doi: 10.11607/prd.3798.

8. Megarbane JM, Kassir AR, Mokbel N, Naaman N. Root resection and hemisection revisited. Part II: a retrospective analysis of 195 treated patients with up to 40 years of follow-up. Int J Periodontics Restorative Dent 2018;38:783789. doi: 10.11607/prd.3797.

9. DeSanctis M, Murphy KG. The role of resective periodontal surgery in the treatment of furcation defects. Periodontol 2000 2000;22:154-168. doi: 10.1034/j.16000757.2000.2220110.x.

10. Klavan B. Clinical observations following root amputation in maxillary molar teeth. J Periodontol 1975;46:1-5. doi: 10.1902/jop.1975.46.1.1.

11. Kasaj A. Root resective procedures vs implant therapy in the management of furcation-involved molars. Quintessence Int 2014;45:521-529. doi: 10.3290/j.qi.a31806.

12. Dietrich T, Zunker P, Dietrich D, Bernimoulin JP. Periapical and periodontal healing after osseous grafting and guided tissue regeneration treatment of apicomarginal defects in periradicular surgery: results after 12 months. Oral Surg Oral Med Oral Pathol Oral Radiol Endod 2003;95:474-482. doi: 10.1067/moe.2003.39.

13. Park SY, Shin SY, Yang SM, Kye SB. Factors influencing the outcome of root-resection therapy in molars: a 10year retrospective study. J Periodontol 2009;80:32-40. doi: 10.1902/jop.2009.080316.

14. Minsk L, Polson AM. The role of root resection in the age of dental implants. Compend Contin Educ Dent 2006;27:384388.

15. Kinsel RP, Lamb RE, Ho D. The treatment dilemma of the furcated molar: root resection versus single-tooth implant 
restoration. A literature review. Int J Oral Maxillofac Implants 1998;13:322-332.

16. Fugazzotto PA. A comparison of the success of root resected molars and molar position implants in function in a private practice: results of up to 15-plus years. J Periodontol 2001;72:1113-1123. doi: 10.1902/jop.2001.72.8.1113.

17. Salvi GE, Mischler DC, Schmidlin K, Matuliene G, Pjetursson BE, Brägger U, Lang NP. Risk factors associated with the longevity of multi-rooted teeth. Long-term outcomes after active and supportive periodontal therapy. J Clin Periodontol 2014;41:701-707. doi: 10.1111/jcpe.12266.

18. Newell DH. The role of the prosthodontist in restoring root-resected molars: a study of 70 molar root resections. J Prosthet Dent 1991;65:7-15. doi: 10.1016/00223913(91)90039-y. 